\title{
Linking Human Resource Management Practices to Organizational Performance in Nigeria Education Sector
}

\author{
Malam Salihu Sabiu', Kabiru Maitama Kura² and Andi Reni ${ }^{3}$
}

\author{
${ }^{1}$ Umaru Ali Shinkafi Polytechnic, Nigeria \\ ${ }^{2}$ Universiti Teknologi Brunei, Brunei Darussalam \\ ${ }^{3}$ Hasanuddin University, Indonesia
}

\begin{abstract}
This study is aimed at examining the relationship between human resource management practices and organizational performance. Training and development and compensation practices were mainly incorporated in our research model. A sample of 181 Education Ministry, boards, parastatals and agencies in seven states of North-Western Nigeria was drawn using stratified proportionate sampling technique. We employed partial least squares path modeling to test our hypothesized model. As expected, we found that training and development had a significant and positive relationship with organizational performance. In the same vein, compensation system was found to be significantly related to organizational performance. Consequently, policy makers, managers and administrators in educational sector are encouraged to provide adequate training to its employees as well as appropriate compensation system need to be able to put in place to promote high employee performance and in return achieve organizational performance.
\end{abstract}

Keywords: training \& development, compensation system, organizational performance, Nigeria

\section{Introduction}

Over the years, the importance of organizational performance (OP) for efficient management is increasing in any given organization. The rapid changes in economic environment is being taken over by such phenomena as the globalization and deregulation of markets, changing customer and investor demand, and the ever-increasing product-market competition has become the norm for most organizations (Saleh, Zien, \& Kaid, 2014). Organizations do not operate in a vacuum but they must attract a wide variety of capital, resources, customers and suppliers to create cooperative and supportive networks (Schute \& Meyer, 2004). Additionally, Chen (2005), stated that organizations both public and private sectors are looking for ways to improve their performance and attain competitive advantage over competitors. Nevertheless, how this performance can be improved and what approaches should be executed towards that, is still the issue that needs to be investigated further. To achieve an enhanced OP, management activities are considered to be one of the most important factors and it is also the most studied approach in the organizational behavior discipline (Agami, Saleh, \& Rasmy, 2012).

In related argument, Noe, Hollenbeck, Gerhart and Wright, (2011) defined Human Resource Management as a philosophy, system, policy and practices that can touch the behavior, attitudes and performance of employees in an organization. Some of the activities of human resource management (HRM) include planning, staffing, performance management, training and development, compensation system, employee relations and safety and health. Earlier, the management/ administrators of organization have neglected the importance of HRM practices as a main predictor of organizational performance (OP) and success. Lately, the vital role of HRM in improving OP has been comprehended. HRM practices can improve the performance of organizations by contributing to employee and customer satisfaction, innovation, productivity, and development of good reputation among firm's community (Delaney \& Huselid, 1996; Noe et al., 2011). However, the performance of Nigerian educational sector administration (PESA) is low performance compared to others countries in the same continents like, South Africa, Algeria, Egypt 
and Tunisia with $69.30 \%, 71.30 \%, 66.20 \%, 67.20 \%$ respectively with Nigeria PESA sitting at $47.20 \%$ considering Nigeria the most populous country in the continent (World Bank, 2013).

Despites the imperative role played by HRM practices towards the realization of OP, many organizations do not give emphases to its effective and efficient utilization to ensure OP in emerging economy like Nigeria. Several studies have been conducted on HRM practices and OP in America, Europe and different parts of Asian countries (Chahal, Jyoti, \& Rani, 2016; DeGeest, Follmer, \& Lanivich, 2016; Fu, Flood, Bosak, Morris, \& O’Regan, 2015; Mufti, Parvaiz, Wahab, \& Durrani, 2015; Obeidat, Mitchell, \& Bray, 2016; Ribeiro \& Gomes, 2016; Yen, Wang, \& Kao, 2016), but little were conducted in Africa in general and Nigeria in particular. Most of those little studies conducted on HRM practices and OP in Nigeria, focus more on individual performance, organization strategy in private organizations like banks, manufacturing firms with little in public sector (Anakwe, 2002; Ogbonnaya \& Valizade, 2016; Tabiu \& Nura, 2013; Tabiu, Pangil, \& Othman, 2016a, 2016b). In addition, studies emphasized on the impacts of HRM practices on employees/ job performance not OP. These theoretical flaws and little practical issues motivate the researchers on the need for yet another study on the effects of HRM practices on OP in Nigerian public educational sector administration (PESA) to fill in the gap.

Training and Development and OP. A training is the formal and systematic modification of behavior through learning which occurs because of education, instruction, development and planned experience (Armstrong, 2014) 2001). Training can be on the job or off the job depending on the need in question. Appropriate training is required for various needs such as: to solve pertinent problems, to boost performance, and for continuous development of human resource. The practice is one of the most important aspects of HRM needed to keep organizations ahead of their competitors (Olaniyan \& Ojo, 2008). A rigorous study conducted by Koch and Mcgrath (1996) demonstrated that firms that engage in systematic training of their workforce are more likely to enjoy the rewards of a more productive workforce. In related argument, Resource Based View (RBV) stress that proper utilization of internal resources may leads to competitive advantage and OP, considering training and development as vital internal factor and will be best way of utilizing internal resources (Sabiu, Mei, \& Joarder, 2016).

Several empirical studies were conducted to confirm the relationship between training and development and OP. For example, study conducted by Saleem and Khurshid (2014) in their empirical investigation on the relationship between training and development to performance in three banks located in Pakistan, result revealed that training and development positively related to individual performance which in turn can enhance OP. Similarly, Akhtar et al. (2014) carried out study in Asian context in higher education institution in Pakistan, 50 sample used for data analysis, the result shows significantly related between the training and development and firm performance. The statistical result discovered that training and development is the determinant of OP. Again, study conducted by Úbeda-García, Marco-Lajara, Sabater-Sempere, and Garcia-Lillo (2013) in Spanish hotel industry with 110 sample, the result revealed that a training is positive significantly related to OP. Additionally, Islam and Siengthai (2010) investigates the link between training and development in Bangladesh industries DEPZ area with 216 sample, result of the study shows that training and development is positively related to OP. Furthermore, study carried out by Abdullah et al. (2009). Asian context research in Malaysia using private firms, 153 sample used in the analysis, the regression results revealed that training and development regarded as highest predictor of performance. Despite the literature reviewed in Asian and Western context, however studies of this nature are still lacking in African context more particularly Nigerian PESA. Hence, the following hypothesis were developed:

H1: There is significant relationship between Training and development and OP

Compensation system and OP. Huselid (1995) stated that the compensation system is known as employee merit and it is commonly linked with organizational outcomes. Compensation can simply refer to all economic payments and all commodities used in its place of monetary incentive 
employees (Islam \& Siengthai, 2010). According to The expectancy theory of Vroom (1964) suggests that rewards, which can be understood as a form of direct and indirect compensation packages, have potential to influence employee work motivation. Thang (2004) Argued that compensation and reward can be influential tools for attaining efforts from the personnel to fulfill the organizational objectives. In Malaysian context, compensation is an important practice that increase job satisfaction (Jauhar et al., 2015) and in return job satisfaction leads to OP (Joarder \& Sharif, 2012; Rodrigues \& Pinho, 2010).

Many empirical studies were carried out to establish the relationship between compensation system and OP, result found significant relationship. The study by Beh and Loo (2013) in Asian context Malaysian insurance firms with 312 sample comprises, the top management, executive, nonexecutive and managers. The quantitative result shows that compensation system positively relate to OP. Similarly, another study conducted by Ko \& Smith-Walter (2013) in USA using 2011 federal employees in survey study, result shows that compensation system is significantly related to performance. Again, Amin, Ismail, Rasid, \& Selemani, (2014) investigates the link between compensation system and OP in Asian context, public university in Malaysia were used, 300 sample of both academicians and administrative staffs. The regression analysis revealed that compensation system is positively significant to performance. Further, study conducted by Akhtar et al. (2014) in Pakistan in higher education with 50 sample, the regression analysis shows that compensation is positive significant to performance. Based on empirical evidences, the researcher will have considered compensation as an important variable in predicting performance. Despite the literature reviewed in Asian and Western context, however studies of this nature are still lacking in African context more particularly Nigerian PESA. Hence, the following hypothesis were developed: $\mathrm{H} 2$ : There is significant relationship between compensation system and OP

\section{Research Methodology}

This study is a survey research and cross sectional in nature and data used for this study were collected between April to July 2016 using a questionnaire instrument that was self-administered and personal administered to 216 ministries of education, boards, agencies and parastatals in seven (7) of Northern Nigeria. From the 216 questionnaires administered 181 questionnaires were usable, duly filled and returned, a response rate close to $81 \%$ percent. To be able to determine the consistency of the study instrument, a content validity was also conducted. All the instruments used in the questionnaire were adapted from various sources with suitable internal consistency reliability and validity were confirmed in the literature. The internal consistency reliability of the construct was evaluated using composite reliability and computed Cronbach's alphas values. Additional, discriminant validity was also assessed to consolidate the authenticity of the study instrument scales.

The model including training and development, compensation system and organizational performance was assessed using two-step approach such as measurement model and structural model (Hair, Hult, Ringle, \& Sarstedt, 2014).

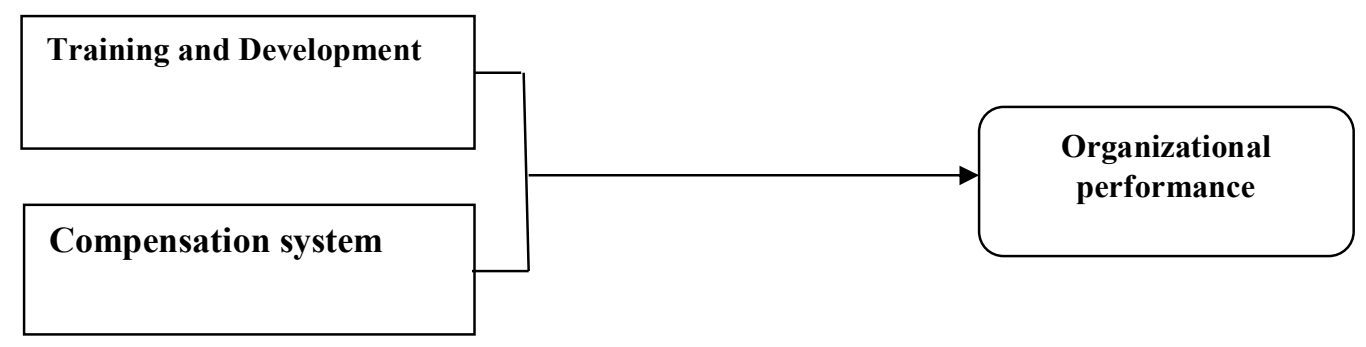

Figure i. Research Framework 


\section{Result and Discussion}

The discussed how the data were collected and analyzed using SmartPLS 3.2.6 (Hair, Hult, Ringle, \& Sarstedt, 2016). Measurement model evaluation was commenced where the composite reliability, Average variance extracted (AVE) and item loadings of the study constructs were assessed as well as discriminant validity were also examined for all the constructs (training and development, compensation system and OP). The structural model assessment was undertaken by testing the path coefficient (hypotheses) among the variables under study were decisions on the supported or rejected of the hypotheses was also indicated, assessment of $R^{2}$ square, effect size $f^{2}$ and predictive relevance of the whole model.

Measurement Model Evaluation. As discussed in previously in methodology section, the study used SmartPLS 3.2.6v (Hair et al., 2016) as the tool for analysis. This instrument analyses data for measurement models which is filtering the model for all the constructs (TD, COM and OP). The measurement model basically determines the reliability of the measurement scales used in the study and it also treats the goodness of fit of the model to be able to determine the global applicability (Ramayah, Lee, \& In, 2011).

Table i. Factor loading, Composite reliability and Convergent validity analysis

\begin{tabular}{llccc}
\hline Constructs & Items & Loadings & Composite reliability & AVE \\
\hline Organizational & OP10 & 0.74 & 0.84 & 0.51 \\
Performance & OP3 & 0.66 & & \\
& OP5 & 0.67 & & \\
& OP6 & 0.68 & & \\
Training and Development & OP7 & 0.80 & 0.52 \\
& TD1 & 0.66 & & \\
& TD2 & 0.72 & & \\
& TD3 & 0.76 & & \\
& TD4 & 0.71 & & \\
& TD5 & 0.73 & & \\
Compensation System & TD6 & 0.73 & & \\
COM1 & TD7 & 0.74 & & \\
& & 0.795 & & \\
& & 0.782 & & \\
& COM2 & 0.692 & & \\
& COM3 & 0.692 & \\
& COM4 & 0.755 & & \\
& COM5 & 0.616 & & \\
& & & & \\
& &
\end{tabular}

Table 1 above shows the results of the factor loadings, composite reliability and AVE calculations of all the constructs (TD, COM and OP). As indicates in the Table 1, the AVE values that range from 0.51 to 0.53 , with consistent composite reliability values also ranging from 0.84 to 0.89 interprets that the items used in this study measured the constructs and show an achievement of convergent validity. Therefore, CR, Factor loadings and AVE in this study are suitable and attained as recommended by Hair et al. (2014).

Table ii. Discriminant Validity (Fornell-lacker criterion)

\begin{tabular}{lrrrr}
\hline & Constructs & COMP & OP & TD \\
\hline COMP & $\mathbf{0 . 7 3}$ & & & \\
OP & 0.39 & & $\mathbf{0 . 7 1}$ & \\
TD & 0.53 & 0.57 & $\mathbf{0 . 7 2}$ \\
\hline
\end{tabular}


Table 2 above presents the evaluation of discriminant validity was conducted to evaluate the degree to which measures of constructs are related. To attained that, the square root of the AVE of each construct was taken into consideration. As shown in Table 2, along the sloping are the values of the square root of the AVE which are higher than all those values that are off the sloping and that confirm suitable discriminant validity. In this respect, this means that loadings above are greater than the loadings and cross loadings.

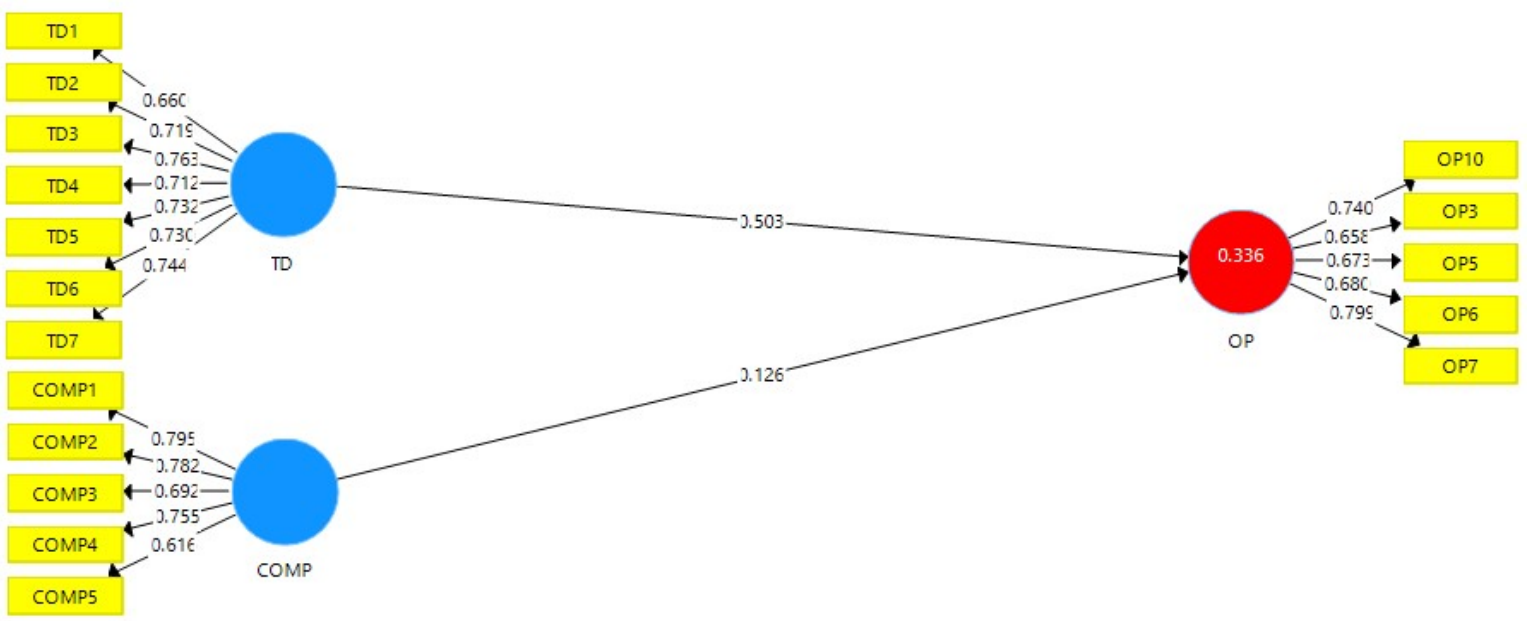

Figure ii. Measurement model (Algorithm)

Structural Model Evaluation. This section discussed the testing of hypotheses, R-square R2, effect size $f 2$, and predictive relevance. It was carried out using bootstrapping output and the decision on the supported or not supported of the hypotheses was based on t-values at $5 \%$ level of significance. Hence, all the hypotheses in this study were supported.

Table iii. Hypotheses for direct relationship between TD->OP, COM and OP

\begin{tabular}{lcrrr}
\hline \multicolumn{1}{c}{ Constructs } & Beta & STD-Error & T -values & Decision \\
\hline TD $->$ OP & 0.50 & 0.07 & 7.36 & Supported \\
COM $->$ OP & 0.13 & 0.07 & 1.70 & Supported \\
\hline$* * * \mathrm{P}<0.001, * * \mathrm{P}<0.01, * \mathrm{P}<0.05$ & & &
\end{tabular}

As indicates in Table 3 above, all the hypotheses found to be significant thus, training and development (TD) and organizational performance (OP) demonstrates significant relationship with a $\beta$ value $=0.50$ and a $t$-value of 7.36. Also, the association between compensation system $(\mathrm{COM})$ and organizational performance (OP) revealed significant relationship with a $\beta$ value $=0.13$ and a tvalue of 1.70 . respectively. 


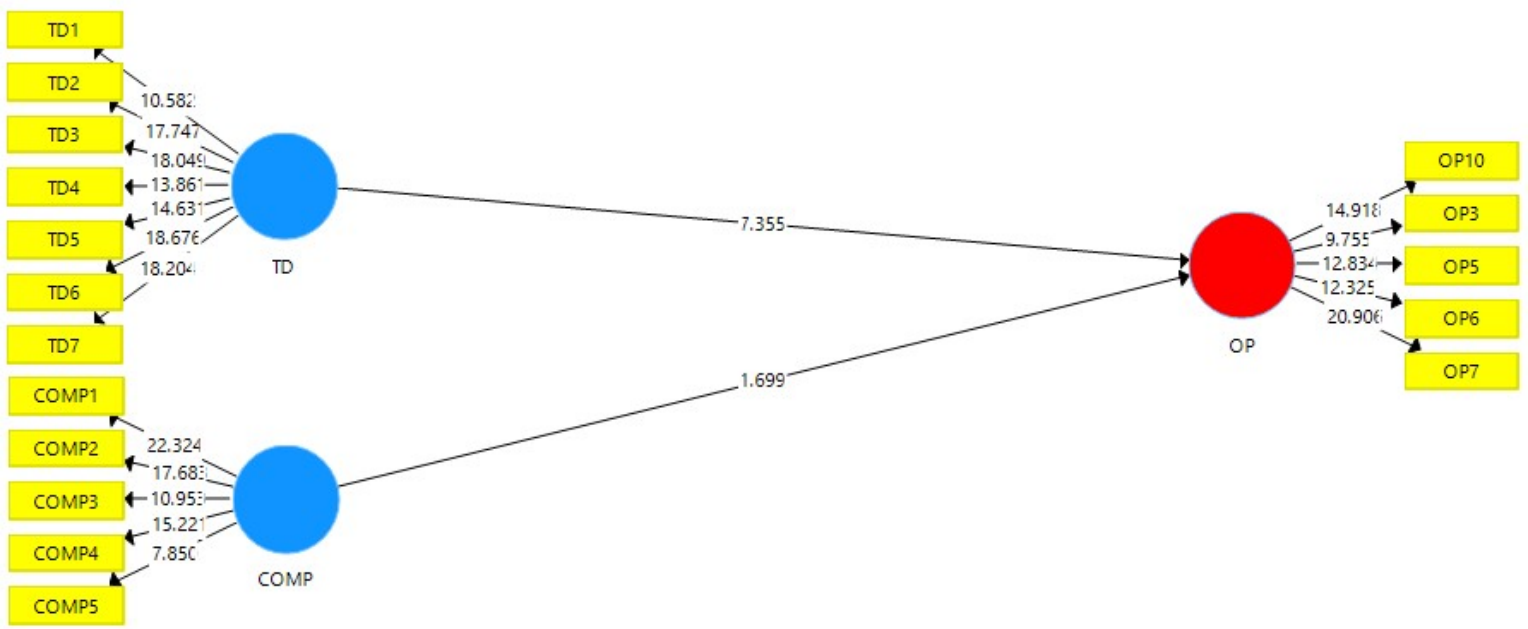

Figure iii. Structural Model (Bootstrapping)

Coefficient of Determination $\left(\mathrm{R}^{2}\right)$. Another conditions used for assessing structural model is Rsquare determination $\left(R^{2}\right)$ of endogenous construct (Hair et al., 2014; Hair et al., 2011, 2012; Henseler et al., 2009). According to Chin (1998); Hair et al. (2011); Hair et al. (2014) and Hair et al. (2016) $R^{2}$ values of $0.75,0.50$ and 0.25 shows substantial, medium and small $R^{2}$ values respectively. Similarly, Falk and Miller (1992) suggests $10 \%$ as a minimum acceptable level of $R^{2}$ value.

Table iv. R-square of endogenous latent constructs

\begin{tabular}{cc}
\hline Constructs & Variance Explained $\left(R^{2}\right)$ \\
\hline Organizational Performance & $34 \%$ \\
\hline
\end{tabular}

From Table 4 above, $R^{2}$ value of all the endogenous construct (OP) is small with (0.34).

Assessment of Effect Size $\left(\mathrm{f}^{2}\right)$. After achieving the coefficient of determination $R^{2}$ of OP, the next assessment is effect size $\left(f^{2}\right)$ as recommended by Hair, Ringle, and Sarstedt (2013). Cohen (1988) describes $f 2$ values of $0.02,0.15$ and 0.35 as having small, medium, substantial effects respectively. However, Chin, Marcolin, and Newted (2003), stress that, smallest strength of $f^{2}$ of exogenous constructs on endogenous variables should be considered with an effect. Henceforth, the effect size for exogenous constructs could be assess using the formula below (Cohen, 1988; Selya, Rose, Dierker, Hedeker, \& Mermelstein, 2012).

$$
\text { Effect size: } f 2=\frac{\mathrm{R}^{2} \text { included }-\mathrm{R}^{2} \text { Excluded }}{1-\mathrm{R}^{2} \text { Included }}
$$

Table v. Assessment of the Effect Size: F-Square

\begin{tabular}{lrrrc}
\hline Constructs & $R^{2}$ Included & $R^{2}$ Excluded & $f$-squared & Effect Size \\
\hline TD-OP & 0.34 & 0.16 & 0.26 & Medium \\
COM-OP & 0.34 & 0.32 & 0.02 & Small \\
\hline
\end{tabular}

Table 5 above presents the effect size values of 0.26 and 0.02 considered as medium and small having acceptable $F$-square values.

Assessment of Predictive Relevance. The researchers assess the predictive capacity of the study model. It was conducted through blindfolding method to determine how the values are assembled around the model. The result of cross validated redundancy was used because it explains how capable the model is to predict the endogenous constructs. It is believed that any model above " 0 " 
has predictive relevance, it has the ability to predict relationship and if the value is " 0 " and below means the model has no any predictive power (Geisser, 1974; Stone, 1974).

Table vi. Predictive relevance Q2

\begin{tabular}{lccr}
\hline Total & SSO & SSE & $1-S S E / S S O$ \\
\hline OP & 905 & 771.011 & 0.15 \\
\hline
\end{tabular}

Note: SSO (sum of square root observations) SSE (sum of square root predictive errors)

From Table 6, column 4, $Q^{2}$ shown an outstanding relevance of 0.15 for the endogenous construct (OP). Therefore, based on Chin (1998), Geisser (1974), and Stone (1974) the model of this study has predictive relevance. (Hair et al., 2014).

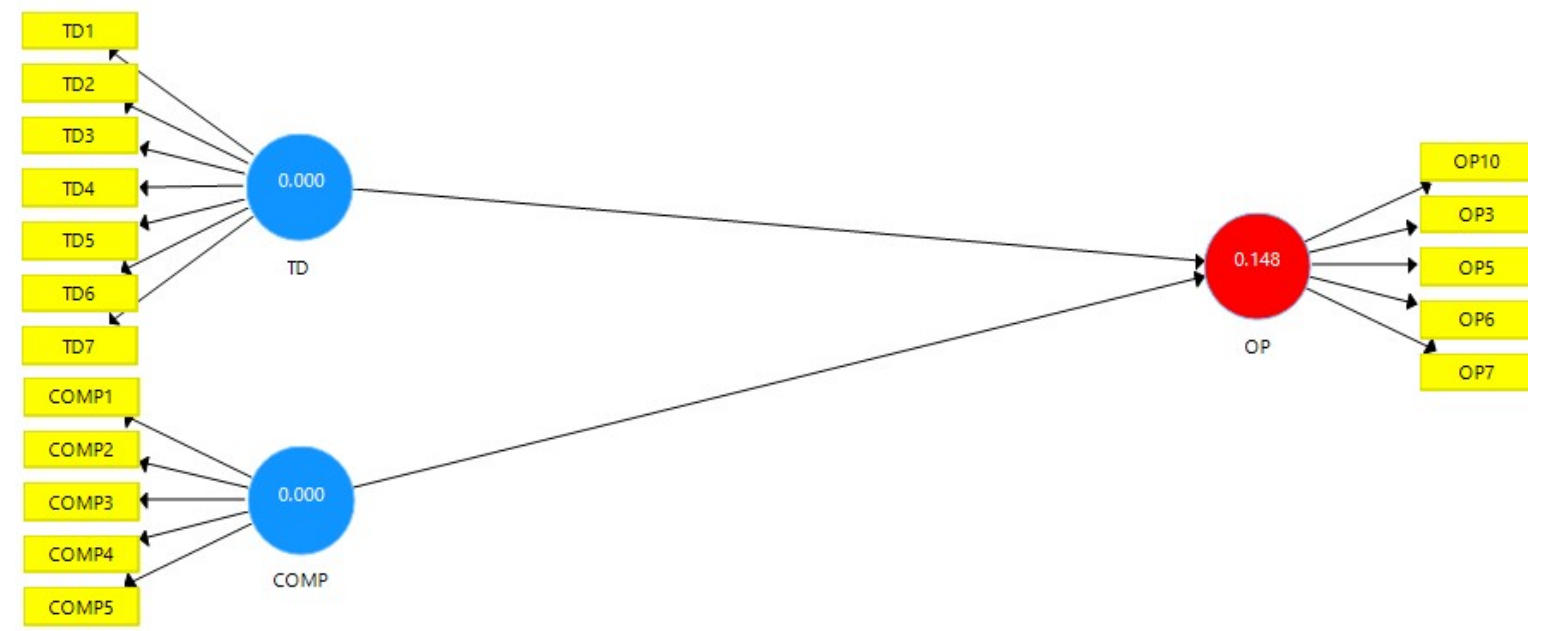

Figure iv. Predictive relevance

The study investigates the relationship between training and development, compensation system and OP. Statistically, result revealed that all the hypotheses were found positively supported. The hypothesis one H1: relationship between training and development and OP is found significant in this study. The finding is consistent with some prior studies (Abdullah et al., 2009; Akhtar etal., 2014; Islam \& Siengthai, 2010; Úbeda-García et al., 2013) who in their studies individually revealed that inadequate training and development of employees hinders OP. Though, training and development considered as internal resources whereby adequate training and development of employees may lead to OP, maximum level of OP depends on the higher level of employee training. In this regard, organizations need to strategies their plans appropriately in utilizing the available internal resources such as training and development. In line with this, it is indicating that if Nigerian PESA comprehensively focus on adequate training of employees in return, will massively contribute to effective OP. Similarly, hypothesis two H2: relationship between compensation system and OP also statistically supported, the result of this study concurred with the findings some previous empirical studies (Amin et al., 2014; Beh \& Loo, 2013; Ko \& Smith-Walter, 2013). This shows that appropriate compensation system leads to superior OP, considering this empirical confirmation, organizations need to put their plans appropriately in utilizing the available internal resources such as compensation system to attain organizational objectives. So, Nigerian PESA needs to focus on appropriate compensation system policy for employees benefit as well as the organization in turn will improve organizational performance.

\section{Conclusion}

This study was conducted to understand the relationship between training and development, compensation system and organizational performance. The study contributes to the existing 
knowledge by examining the relationship between training and development, compensation system and OP in Nigerian educational sector administration empirically. Basically, the results of this study will help the managers, administrators, policy makers/stakeholders and policy implementation committee in Nigerian PESA ministries, parastatals, boards and the agencies are encouraging to ensure and provide adequate training to its employees as well as appropriate compensation system need to be put in place to promote high employee performance and in return achieve organizational performance. Finally, the study recommends the use of large sample, other country educational sector administration can also conduct a similar study using other groups of practices to replicate the result of the present study. Future research can use smart PLS, Amos or any other secondgeneration analysis technique to re-confirm the model.

\section{References}

Abdullah, Z., Ahsan, N., \& Alam, S. S. (2009). The Effect of Human Resource Management Practices on Business Performance among Private Companies in Malaysia. International Journal of Business and Management, 4(6), 65-72. http://doi.org/10.3968/j.css.1923669720120802.2256

Agami, N., Saleh, M., \& Rasmy, M. (2012). Supply Chain Performance Measurement Approaches: Review and Classification. The Journal of Organizational Management Studies, 2012(2012), 1-20. http://doi.org/10.5171/2012.872753

Akhtar, N., Azeem, S. M., \& Mustafa Mir, G. (2014). Impact of HRM practices on percieved organisational performance. International Journal of Academic Research, (6), 5.

Amin, M., Ismail, W. K. W., Rasid, S. Z. A., \& Selemani, R. D. A. (2014). The impact of human resource management practices on performance: Evidence from a Public University. The TQM Journal, 26(2), 125-142. http://doi.org/10.1108/TQM-10-2011-0062

Anakwe, U. P. (2002). Human resource management practices in Nigeria: challenges and insights. The International Journal of Human Resource Management, 13(7), 1042-1059. http://doi.org/10.1080/09585190210131285

Armstrong, M. (2014). Armstrong's handbook of human resource management practice. Handbook of human resource management practice.

Beh, L., \& Loo, L. (2013). Human resource management best practices and firm performance: a universalistic perspective approach. Serbian Journal of Management, 8(2), 155-167. http://doi.org/10.5937/sjm8-4573

Chahal, H., Jyoti, J., \& Rani, A. (2016). The Effect of Perceived High-performance Human Resource Practices on Business Performance: Role of Organizational Learning. Global Business Review, 17(3S), 1S-25S. http://doi.org/10.1177/0972150916631193

Chen, H.-L. (2005). A competence-based strategic management model factoring in key success factors and benchmarking. Benchmarking: An International Journal, 12(4), 364-382. http://doi.org/10.1108/14635770510609033

Chin, W. W. (1998). The partial least squares approach to structural equation modeling. In Modern Methods for Business Research (Vol. 295, pp. 295-336). http://doi.org/10.1016/j.aap.2008.12.010

Chin, W. W., Marcolin, B. L., \& Newted, P. R. (2003). A Partial least Squares Latent Variable Modeling Approach for Measuring Interaction Effects: Results From a Monte Carlo Simulation Study and Voice Mail Emotion/Adoption Study. Proceedings of the Seventeenth International Conference on Information Systems, 21-41. http://doi.org/10.1287/isre.14.2.189.16018

Cohen, J. (1988). Statistical power analysis for the behavioral sciences. Statistical Power Analysis for the Behavioral Sciences. http://doi.org/10.1234/12345678

DeGeest, D. S., Follmer, E. H., \& Lanivich, S. E. (2016). Timing Matters: When High-Performance Work Practices Enable New Venture Growth and Productivity. Journal of Management, 
$X X(\mathrm{X}), 1-28$. http://doi.org/10.1177/0149206316652481

Delaney, J. T., \& Huselid, M. A. (1996). The Impact of Human Resource Management Practices on Perceptions of Organizational Performance. Academy of Management Journal, 39(4), 949969. http://doi.org/10.2307/256718

Falk, R. F., \& Miller, N. B. (1992). A primer for soft modeling. Ohio: The University of Akron Press. The University of Akron Press.

Fu, N., Flood, P. C., Bosak, J., Morris, T., \& O’Regan, P. (2015). How do high performance work systems influence organizational innovation in professional service firms? Employee Relations, 37(2), 209-231. http://doi.org/10.1108/JFM-03-2013-0017

Geisser, S. (1974). A predictive approach to the random effect model. Biometrika, 61, 101-107. http://doi.org/10.1093/biomet/61.1.101

Hair, J. F., Hult, G. T. M., Ringle, C., \& Sarstedt, M. (2016). A primer on partial least squares structural equation modeling (PLS-SEM). Sage Publications.

Hair, J. F. J., Hult, G. T. M., Ringle, C., \& Sarstedt, M. (2014). A Primer on Partial Least Squares Structural Equation Modeling (PLS-SEM). Long Range Planning (Vol. 46). http://doi.org/10.1016/j.lrp.2013.01.002

Hair, J. F., Ringle, C. M., \& Sarstedt, M. (2011). PLS-SEM: Indeed, a Silver Bullet. The Journal of Marketing Theory and Practice, 19(2), 139-152. http://doi.org/10.2753/MTP10696679190202

Hair, J. F., Ringle, C. M., \& Sarstedt, M. (2013). Partial Least Squares Structural Equation Modeling: Rigorous Applications, Better Results and Higher Acceptance. Long Range Planning, 46(1-2), 1-12. http://doi.org/10.1016/j.lrp.2013.01.001

Hair, J. F., Sarstedt, M., Ringle, C. M., \& Mena, J. A. (2012). An assessment of the use of partial least squares structural equation modeling in marketing research. Journal of the Academy of Marketing Science, 40(3), 414-433. http://doi.org/10.1007/s11747-011-0261-6

Henseler, J., Ringle, C. M., \& Sinkovics, R. R. (2009). The use of partial least squares path modeling in international marketing. Advances in International Marketing, 20(1), 277-319. http://doi.org/10.1016/0167-8116(92)90003-4

Huselid, M. A. (1995). The impact of human resource management practices on turnover, productivity, and corporate financial performance. Academy of Management Journal, 38(3), 635-672. http://doi.org/10.2307/256741

Islam, Z., \& Siengthai, S. (2010). Human Resource Management Practices and Firm Performance Improvement in Dhaka Export Processing Zone (Depz). Research \& Practice in Human Resource Management, 18(1), 60-77.

Joarder, M., \& Sharif, M. (2012). Mediating Role of Organizational Commitment on Hrm Practices and Turnover Intention Relationship: an Empirical Evidence. Pakacademicsearch.Com, 4(2), $57-69$.

Ko, J., \& Smith-Walter, A. (2013). The relationship between hrm practices and organizational performance in the public sector: Focusing on mediating roles of work attitudes. International Review of Public Administration, 18(3), 209-231. http://doi.org/10.1080/12294659.2013.10805270

Koch, M. J., \& Mcgrath, R. G. (1996). Improving Labor Productivity: Human Resource Management Policies do Matter Stable URL: http://www.jstor.org/stable/2486699 REFERENCES Linked references are available on JSTOR for this article: You may need to $\log$ in to JSTOR to access the linked refere. Strategic Management Journal, 17(5), 335-354.

Mufti, O., Parvaiz, G. S., Wahab, M., \& Durrani, M. (2015). Human Resource Competencies and Organizational Performance: A Study on Banking Sector Managers in. Journal of Managerial Sciences, 10(1), 83-101.

Noe, R. a, Hollenbeck, J. R., Gerhart, B., \& Wright, P. M. (2011). Fundamentals of Human Resource Management. Human Resource Management. 
Obeidat, S. M., Mitchell, R., \& Bray, M. (2016). The link between high performance work practices and organizational performance Empirically validating the conceptualization of HPWP according to the AMO model Shatha. Employee Relations, 38(4), 578-595. http://doi.org/http://dx.doi.org/10.1108/MRR-09-2015-0216

Ogbonnaya, C., \& Valizade, D. (2016). High performance work practices, employee outcomes and organizational performance: a 2-1-2 multilevel mediation analysis. The International Journal of Human Resource Management, 5192(August), 0-21. http://doi.org/http://dx.doi.org/10.1080/09585192.2016.1146320

Olaniyan, D. A., \& Ojo, L. B. (2008). Staff Training and Development: A Vital Tool for Organisational Effectiveness. European Journal of Scientific Research, 24(3), 1450-216. Retrieved from http://www.eurojournals.com/ejsr.htm

Ramayah, T., Lee, J. W. C., \& In, J. B. C. (2011). Network collaboration and performance in the tourism sector. Service Business, 5(4), 411-428. http://doi.org/10.1007/s11628-011-0120-z

Ribeiro, J. L., \& Gomes, D. (2016). Other Organizational Perspectives on the Contribution of Human. Spiringer, 3(4), 63-106.

Rodrigues, A. P., \& Pinho, J. C. M. R. (2010). Market orientation, job satisfaction, commitment and organisational performance: The specific case of local public sector. Transforming Government: People, Process and Policy, 4(2), 172-192. http://doi.org/10.1108/17506161011047398

Sabiu, M. S., Mei, T. S., \& Joarder, M. H. R. (2016). Moderating role of ethical climates on HRM practices and organizational performance: A proposed conceptual model. Mediterranean Journal of Social Sciences, 7(1), 291-300. http://doi.org/10.5901/mjss.2016.v7n1p291

Saleem, I., \& Khurshid, A. (2014). Do Human Resource Practices affect Employee Performance? Pakistan Business Review, 15(4), 669-688.

Saleh A, H., Zien B, R., \& Kaid A, A. (2014). The relationship between enterprise resource planning, total quality management, organizational excellence, and organizational performance-the mediating role of total quality management and organizational excellence. Asian Social Science, 10(14), 158-178. http://doi.org/10.5539/ass.v10n14p158

Schute, N., \& Meyer, M. E. (2004). Strategic Management in the South African Police Service: An Examination of Management Preparedness.

Selya, A. S., Rose, J. S., Dierker, L. C., Hedeker, D., \& Mermelstein, R. J. (2012). A practical guide to calculating Cohen's f 2, a measure of local effect size, from PROC MIXED. Frontiers in Psychology, 3(APR). http://doi.org/10.3389/fpsyg.2012.00111

Stone, M. (1974). Cross-Validatory Choice and Assessment of Statistical Predictions. Journal of the Royal Statistical Society, 36(2), 111-147. http://doi.org/10.2307/2984809

Tabiu, A., \& Nura, A. A. (2013). Assessing the Effects of Human Resource Management (Hrm) Practices on Employee Job Performance: a Study of Usmanu Danfodiyo University Sokoto. Journal of Business Studies Quarterly, 5(2), 247-259.

Tabiu, A., Pangil, F., \& Othman, S. Z. (2016a). Examining the link between HRM Practices and Employees' performance in Nigerian public sector. Management Science Letters, 6, 395-408. http://doi.org/10.5267/j.msl.2016.4.006

Tabiu, A., Pangil, F., \& Othman, S. Z. (2016b). HRM Practices and Employee Performance: The Mediation Effect of Ability, Motivation and Opportunity. Asian Journal of Multidisciplinary Studies, 8819(7), 95-101.

Thang, L. (2004). Managing Human Resources in Vietnam: An empirical study of an economy in transition. Doctoral Dissertation. Asian Institute of Technology.Thailand.

Úbeda-García, M., Marco-Lajara, B., Sabater-Sempere, V., \& Garcia-Lillo, F. (2013). Training policy and organisational performance in the Spanish hotel industry. The International Journal of Human Resource Management, 24(15), 2851-2875. http://doi.org/10.1080/09585192.2012.750617 
Vroom, V. H. (1964). Work and motivation. San Francisco, CA: Jossey-Bass.

WorldBank. (2013). Human Development Report 2013 Retrieved 18th, Monday 2015.

Yen, Y.-F., Wang, H.-K., \& Kao, W. (2016). High-performance work practices and organisational performance in small firms: the role of guanxi. Total Quality Management \& Business Excellence, 27(5/6), 628-646. http://doi.org/10.1080/14783363.2015.1032924 